\title{
Combined Food (Bekatul dan Lemak) Menurunkan Kadar Kolesterol Total, Trigliserida, dan LDL pada Tikus Galur Wistar
}

\author{
Combined Food (Rice Bran and Fat) Reduce of the Total Cholesterol Levels, Triglycerides, and LDL \\ of Wistar Strain Rats
}

Nur Nashriana J, Bambang Wirjatmadi, Merryana Adriani

Departemen Gizi Masyarakat Fakultas Kesehatan Masyarakat Universitas Airlangga Surabaya

\begin{abstract}
ABSTRAK
Bekatul merupakan bahan pangan nabati yang berpotensi menurunkan kolesterol karena kandungan serat pangan yang tinggi dan komponen bioaktif seperti oryzanol, fitosterol dan tokoferol serta tokotrienol. Tujuan penelitian ini adalah untuk menganalisis efek pemberian diet komibnasi bekatul dan tinggi kolesterol terhadap kadar kolesterol total, trigliserida dan LDL pada tikus galur wistar. Penelitian ini merupakan penelitian eksperimen dengan rancangan randomized post test only control group design. Dalam penelitian ini 25 ekor tikus galur wistar dibagi menjadi 5 kelompok secara acak diberi perlakuan selama 4 minggu. Kelompok (K-) diberi diet standar, $(\mathrm{K}+$ ) diberi diet standar dan tinggi kolesterol, (P1) diberi diet standar, tinggi kolesterol dan bekatul 10\%, (P2) diberi diet standar, tinggi kolesterol dan bekatul $30 \%$, (P3) diberi diet standar, tinggi kolesterol dan bekatul 50\%. Kadar kolesterol total diukur menggunakan metode CHODPAP, trigliserida menggunakan metode GPO-PAP dan LDL menggunakan metode homogen assay. Data dianalisis menggunakan One Way ANOVA dan Tukey HSD. Pemberian bekatul dan diet tinggi kolesterol secara bersamaan memberikan kadar kolesterol total $(p=0,000)$, trigliserida $(p=0,001)$, dan $\operatorname{LDL}(p=0,048)$ yang lebih rendah secara bermakna dibandingkan kondisi diet hiperkolesterol. Dosis bekatul sebesar $50 \%$ (P3) memberikan penurunan bermakna kadar kolesterol, trigliserida dan LDL hingga sama dengan kondisi normal. Pemberian bekatul dan diet tinggi kolesterol secara bersamaan dapat menurunkan kadar kolesterol total, trigliserida dan LDL pada tikus galur wistar dengan dosis efektif $50 \%$.
\end{abstract}

Kata Kunci: Bekatul, combined food, kolesterol total, LDL, trigliserida

\section{ABSTRACT}

Rice bran is a food source that has potential to lower the cholesterol because of the high content of dietary fiber and bioactive components such as oryzanol, phytosterols, tocopherols, and tocotrienols. The purpose of this research is to analyze the provision of rice bran and high cholesterol diet on total cholesterol, triglycerides, and LDL in wistar strain rats. This is an experimental research with a randomized post-test only control group design. In this research, 25 wistar strain rats were divided randomly into 5 groups and were treated for 4 weeks. Group (K-) was given a standard diet, $K(+)$ was given a standard diet and high cholesterol, (P1) was given a standard diet, high cholesterol and 10\% rice bran, (P2) was given a standard diet, high cholesterol and 30\% rice bran, (P3) was given a standard diet, high cholesterol and $50 \%$ bran. Total cholesterol level was measured using the CHOD-PAP method, triglyceride using the GPO-PAP method and LDL usinga homogeneous assay method. Data were analyzed using One Way ANOVA and Tukey HSD. Simultaneous provision of rice bran and high-cholesterol diet lowered total cholesterol levels significantly $(p=0,000)$, triglycerides $(p=0,001)$ and $L D L$ $(p=, 048)$ compared to hypercholesterol dietary conditions. Rice bran dose of $50 \%$ (P3) provides a significant reduction in the levels of cholesterol, triglycerides, and LDL up to as same as the normal condition. Rice bran and high cholesterol diet simultaneously can reduce total cholesterol, triglycerides and LDL in wistar strain rats in which effective dose is $50 \%$.

Keywords: Combined Food, LDL, total Cholesterol, triglycerides, Rice bran

Jurnal Kedokteran Brawijaya, Vol. 28, No. 3, Februari 2015; Korespondensi: Nur Nashriana. Departemen Gizi Masyarakat Fakultas Kesehatan Masyarakat Universitas Airlangga Surabaya, Jl. Mulyorejo Kampus C Surabaya Telp (031) 5920948 Email: nurnashrianajufri@yahoo.co.id 


\section{PENDAHULUAN}

Lemak merupakan suatu makro molekul yang sangat diperlukan oleh makhluk hidup karena perannya yang sangat penting sebagai sumber energi tinggi dan sebagai pelarut beberapa vitamin yang tidak larut dalam air, yaitu vitamin $A, D, E$, dan $K(1)$. Konsumsi lemak yang berlebihan akan mengakibatkan peningkatan jumlah senyawa kolesterol dan trigliserida di dalam darah. Oksidasi trigliserida dan kolesterol menyebabkan pembentukan radikal bebas yang diketahui dapat merusak sel-sel endotel. Jika oksidasi trigliserida dan kolesterol terjadi di sel endotel maka akan terjadi aterosklorosis yaitu penyakit kronis yang ditandai dengan penebalan dan pengerasan dinding arteri akibat adanya lesi yang mengandung deposit lipid yang menyebabkan obstruksi pembuluh darah, agregrasi trombosit, dan fase konstriksi abnormal (2).

Penelitian Interheart dalam Bull dan Morrel (3) yang dilakukan pada 52 negara yang mencakup 30.000 orang menunjukkan bahwa hampir $50 \%$ serangan jantung dapat dikaitkan dengan kadar kolesterol darah yang abnormal. Orang dengan kadar kolesterol yang abnormal, tiga kali lebih mudah mendapat serangan jantung dan penyakit kardiovaskuler dibandingkan mereka yang memiliki kadar kolesterol normal. Pada tahun 2003, di Inggris lebih dari 114.000 orang meninggal akibat penyakit jantung koroner, 233.000 orang meninggal akibat penyakit kardiovaskuler dan 259.500 orang mengalami serangan jantung.

Salah satu upaya untuk menurunkan kadar kolesterol dalam darah yaitu dengan memperbanyak konsumsi serat pangan (dietary fiber). Serat pangan dapat menghambat absorpsi kolesterol dalam usus halus dan akhirnya akan menurunkan kolesterol dalam plasma serta meningkatkan sintesis kolesterol oleh hati, sintesis empedu, dan eksresi kolesterol melalui feses. Oleh karena itu, serat pangan telah banyak digunakan dan direkomendasikan untuk menjaga kolesterol darah agar tetap normal (4).

Bekatul merupakan salah satu bahan makanan serealia hasil sampingan yang diperoleh dari lapisan luar beras pecah (5). Serat pangan (dietary fiber) serta minyak yang terkandung di dalam bekatul dipercaya dapat menurunkan kadar kolesterol dalam darah. Telah banyak penelitian yang membuktikan bahwa serat yang terdapat dalam bekatul dapat menurunkan kadar kolesterol dalam plasma dan hati.

Bekatul juga mengandung komponen bioaktif Fitosterol yang berguna sebagai zat hipokolesterolemik atau dapat menurunkan kadar kolesterol darah. Fitosterol menurunkan kolesterol dengan cara menghambat absorbs kolesterol dari makanan, dan menghambat reabsorbsi kolesterol asam empedu dengan cara memodifikasi Asetil Ko-A karboksilase dan aktifitas $7 \alpha$ dehidroksilase sehingga terjadi peningkatan eksresi asam empedu melalui feses. Hal tersebut menyebabkan jumlah asam empedu berkurang sehingga akan meningkatkan pembentukan asam empedu baru dari kolesterol yang ada di dalam darah. Penelitian ini bertujuan untuk menganalisis peran combined food (bekatul dan lemak) terhadap kadar kolesterol total, trigliserida dan LDL pada tikus galur Wistar.

\section{METODE}

Penelitian ini merupakan penelitian eksperimental dengan menggunakan rancang bangun randomized post test only control group design. Penelitian dilakukan di Laboratorium Biokimia Fakultas Kedokteran Universitas Airlangga untuk pemeliharaan dan pemberian perlakuan. Pemeriksaan kolesterol total, trigliserida dan LDL dilakukan di salah satu laboratorium di Surabaya.

Hewan coba yang digunakan adalah tikus putih jantan galur wistar usia 12 minggu, berat badan 180-200 gram sebanyak 25 ekor yang didapat dari Laboratorium Biokimia Universitas Airlangga. Tikus ditempatkan dalam kandang berupa kotak plastik $\left(30 \times 40 \times 40 \mathrm{~cm}^{3}\right)$ yang dilengkapi tempat makan dan botol air minum. Uji kelaikan etik penelitian dikeluarkan oleh komisi penelitian kesehatan fakultas kesehatan masyarakat universitas Airlangga dengan No. 283-KEPK. Bahan pakan yang digunakan adalah untuk pakan standar menggunakan formula Unair, sedangkan pakan tinggi kolesterol menggunakan kuning telur bebek, dan untuk pakan percobaan menggunakan pakan standar, pakan tinggi kolesterol dan campuran bekatul dengan dosis yang berbeda.

Penelitian dilakukan dengan desain Rancangan Acak Lengkap (RAL) dengan 5 kelompok perlakuan. K- adalah kelompok yang hanya diberi diet standar, $\mathrm{K}+$ adalah kelompok yang diberi diet standar dan diet tinggi kolesterol, P1 adalah kelompok yang diberi diet standar, tinggi kolesterol dan bekatul 10\%, P2 adalah kelompok yang diberi diet standar, tinggi kolesterol dan bekatul 30\%, dan P3 adalah kelompok yang diberi diet standar, tinggi kolesterol dan bekatul $50 \%$.

Pada akhir masa percobaan tikus dipuasakan selama 12 jam, kemudian dilakukan pengorbanan. Darah diambil dari vertikel jantung sebanyak $\pm 3-4 \mathrm{ml}$, setelah itu darah di sentrifus selama 15-20 menit dengan kecepatan 3000 rpm untuk memperoleh serum yang digunakan untuk pemeriksaan kolesterol total menggunakan metode CHOD-PAP (6), trigliserida menggunakan metode GPO-PAP dan LDL menggunakan metode homogen assay (7). Data yang diperoleh dianalisis menggunakan One Way ANOVA dan perbedaan antar kelompok dianalisis menggunakan Tukey HSD menggunakan program SPSS for Windows.

\section{HASIL}

\section{Efek Combined Food Bekatul terhadap Kadar Kolesterol}

Secara keseluruhan hasil penelitian menunjukkan bahwa pemberian combined food bekatul mampu memberikan kadar kolesterl total, trigliserida, dan LDL yang lebih rendah dibandingkan kondisi diet hiperkolesterol.

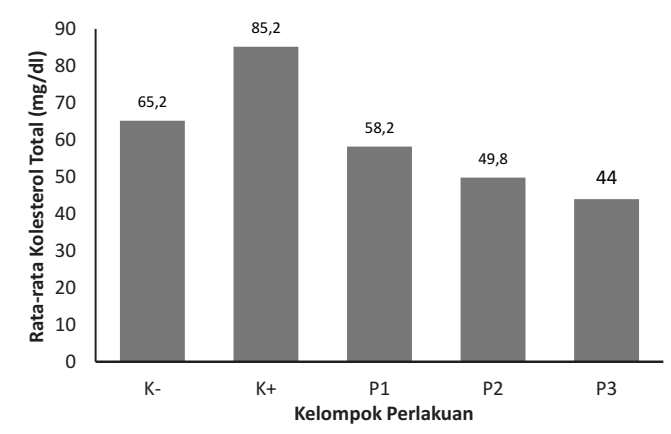

Gambar 1. Rata-rata kadar kolesterol total setelah perlakuan selama 4 minggu 
Berdasarkan hasil uji ANOVA diketahui bahwa rata-rata kadar kolesterol total dari kelima kelompok pada akhir masa perlakuan secara signifikan adalah berbeda dengan nilai $p=0,000 \quad(p<0,05)$. Oleh karena itu, dilanjutkan dengan Tukey HSD untuk mengetahui lebih lanjut perbedaan yang terjadi antar kelompok. Hasil uji Tukey HSD menunjukkan bahwa pemberian diet standar dan tinggi kolesterol $(\mathrm{K}+)$ mempunyai kadar kolesterol yang lebih tinggi $(p=0,001)$ dibandingkan diet standar saja (K-). Pemberian kombinasi diet dengan bekatul pada semua proporsi memberikan kadar kolesterol yang lebih rendah secara signifikan $(p=0,000)$ dibandingkan dengan diet tinggi kolesterol $(\mathrm{K}+)$. Peningkatan proporsi bekatul dari $10 \%$ menjadi $30 \%$ (P2) tidak memberikan perbedaan bermakna $(p=0,335)$. Perbedaan bermakna ditemukan pada diet kombinasi bekatul $50 \%(p=0,029)$.

\section{Efek Combined Food pada Kadar Trigliserida}

Rata-rata Kadar Trigliserida pada akhir perlakuan selama 4 minggu disajikan pada Gambar 2.

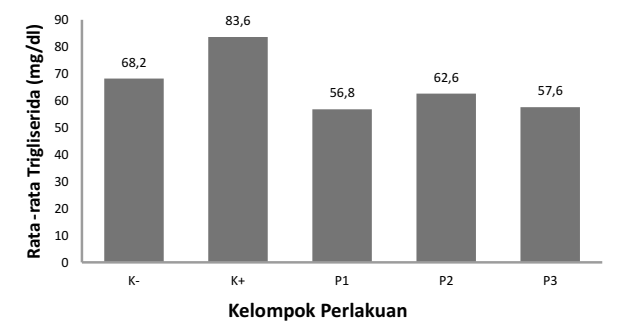

Gambar 2. Rata-rata kadar trigliserida setelah perlakuan selama 4 minggu

Berdasarkan hasil uji ANOVA diketahui bahwa rata-rata kadar trigliserida dari kelima kelompok pada akhir perlakuan pada akhir masa perlakuan secara signifikan adalah berbeda dengan nilai $p=0,001(p<0,05)$. Hasil uji Tukey HSD menunjukkan tidak ada perbedaan bermakna antara kelompok P1 dan P3 $(p=0,827)$, kelompok P2 dan P3 $(p=0,890)$ serta kelompok P2 dan P3 $(p=0,890)$. Terdapat perbedaan bermakna antara kelompok $\mathrm{K}(+)$ dengan kelompok $\mathrm{K}(+)$ dengan P2 $(p=0,008)$, serta kelompok $\mathrm{K}(+)$ dengan P3 $(p=0,001)$. Hal ini menunjukkan bahwa pemberian bekatul memberikan kadar kolesterol yang lebih rendah secara bermakna pada ketiga dosis, dibandingkan dengan kelompok $\mathrm{K}(+)$ (kondisi hiperkolesterol). Tidak ada perbedaan yang bermakna kadar kolesterol antar tiga dosis bekatul yang berbeda. Hal tersebut menunjukkan bahwa pemberian bekatul dengan dosis yang berbeda mempunyai efek yang sama dalam menurunkan kadar trigliserida tikus.

Efek Combined Food Bekatul pada Kadar LDL

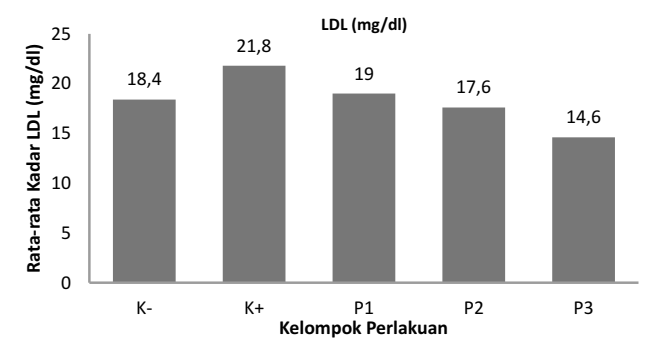

Gambar 3. Rata-rata kadar LDL setelah perlakuan selama 4 minggu
Penelitian ini menunjukkan bahwa perlakuan diet kombinasi bekatul menunjukkan perbedaan signifikan kadar LDL pada beberapa dosis $(p=0,048)$. Dari hasil uji Tukey HSD diketahui hanya antara kelompok $\mathrm{K}(+)$ dan kelompok P3 yang berbeda secara signifikan $(p=0,024)$, sedangkan kelompok perlakuan yang lain tidak menunjukkan perbedaan secara bermakna. Hal ini menunjukkan bahwa diet kombinasi bekatul sebesar $50 \%$ baru dapat kelompok perlakuan P3 mempunyai efek yang lebih baik dalam penurunan kolesterol LDL dibandingkan kelompok P1 dan P2.

\section{DISKUSI}

\section{Pengaruh Pemberian Combined Food Bekatul terhadap} Kolesterol Total

Hasil penelitian menunjukkan terjadi penurunan kadar kolesterol pada kelompok yang diberi bekatul dengan dosis yang berbeda. Hal ini sejalan dengan penelitian Hernawati et al yang menyatakan bahwa terjadi perbaikan profil lipid setelah mencit hiperkolesterolimia disuplementasi dengan pangan bekatul (4). Hal ini dikarenakan bekatul mengandung serat yang sangat berperan dalam menghambat penyerapan kolesterol di usus dan mengganggu sintesis kolesterol di hati. Aksi utama penurunan penyerapan kolesterol pada pakan berserat tinggi dapat disebabkan oleh peningkatan eksresi lemak, asam empedu, dan kolesterol. Sebagai akibatnya terjadi penurunan pengiriman makanan dalam bentuk kilomikron yang berakibat langsung pada pengurangan kolesterol di dalam hati. Serat pangan bekatul juga diduga dapat meningkatkan aktivitas enzim kolesterol-7 $\alpha$ hidroksilase yang mampu berkontribusi terhadap pengurangan kolesterol hati (8). Pengurangan kolesterol di hati mengarah pada stimulasi aktivitas enzimatik 3hidroksi-3-metilglutaril koenzim A (HMG-COA) reduktase untuk meningkatkan sintesis kolesterol endogen (9). Peningkatan eksresi asam empedu melalui feses akan berakibat jumlah asam empedu dalam enterohepatik menurun. Hati akan memproduksi asam empedu dengan cara menarik kolesterol dalam darah lebih banyak, sehingga konsentrasi kolesterol dalam darah menurun (10).

Diet yang mengandung banyak serat menyebabkan penundaan absorpsi bahan makanan di usus termasuk penundaan absorbsi karbohidrat, akibatnya kadar glukosa post pandrial menurun. Keadaan ini menyebabkan sekresi insulin menurun. Sekresi insulin sejalan dengan kerja enzim HMG-koA reduktase, sehingga jika sekresi insulin berkurang maka akan diikuti dengan penghambatan kerja enzim HMG-koA reduktase akibatnya sintesis kolesterol ikut menurun (11).

Bekatul berpotensi menurunkan kolesterol darah terutama karena mengandung serat dan komponen yang tidak tersabunkan. Komponen yang tidak tersabunkan adalah oryzanol, senyawa fitosterol campesterol, dan bsitosterol. Komponen oryzanol, senyawa fitosterol campesterol dan B-sitosterol dapat berperan sebagai antioksidan dan sebagai inhibitor kompetitif dalam penyerapan dan sintesis kolesterol.Fitosterol yang terdapat pada bekatul juga memiliki efek hipokolesterolemik yang dapat menghambat absorpsi kolesterol baik yang berasal dari makanan maupun empedu karena kesamaan dari struktur fitosterol dan kolesterol (12).

Pengaruh Pemberian Combined Food Bekatul terhadap 


\section{Kadar Trigliserida}

Hasil penelitian menunjukkan terjadi penurunan kadar trigliserida secara bermakna pada kelompok yang diberi bekatul dengan dosis yang berbeda. Penelitian yang sejalan dengan hal ini adalah penelitian yang dilakukan oleh Faridzka yang menyebutkan terjadi penurunan kadar trigliserida pada tikus putih (Rattus Novergicus) setelah diberi nata de coco selama 2 minggu (13). Kandungan serat yang terdapat dalam nata de coco dapat menurunkan kadar trigliserida hingga $23,09 \mathrm{mg} / \mathrm{dl}$ atau sekitar 20,98\%. Penelitian yang dilakukan Yamada mengemukakan bahwa kadar trigliserida serum berkorelasi positif dengan kadar kolesterol serum (14). Jika kadar kolesterol meningkat maka akan diikuti dengan peningkatan kadar trigliserida begitupun sebaliknya jika kadar kolesterol menurun maka akan diikuti oleh penurunan trigliserida.

Hernawati dalam penelitiannya juga menyebutkan penurunan kadar trigliserida dan LDL berhubungan dengan penurunan kolesterol total (4). Hubungan penurunan tersebut bersifat searah, yaitu apabila kadar kolesterol mengalami penurunan maka trigliserida dan LDL serum juga akan menurun. Induksi dari serat pangan bekatul, akan memenuhi kebutuhan kolesterol dalam hati dan meningkatkan penyerapan kolesterol bebas yang terikat dengan lipoprotein plasma, pelepasan kolesterol bebas dari penyimpanan intraseluler dalam bentuk ester kolesterol dan membran kolesterol atau dengan sintesis kolesterol hati.

Komponen bekatul yang dapat menurunkan kolesterol total, trigliserida dan LDL adalah minyak, fraksi tak tersabunkan, oryzanol, dan serat pangan larut. Bekatul merupakan sumber serat pangan (serat larut dan serat tidak larut) yang baik. Serat larut terbukti mampu menurunkan kadar LDL dan kolesterol darah serta trigliserida sehingga mampu mencegah terjadinya hiperkolesterolimia dan aterosklerosis (15). Selain serat pangan, bekatul juga mengandung komponen bioaktif oryzanol dan tokoferol. Beberapa penelitian menunjukkan bahwa oryzanol dapat menurunkan kadar kolesterol pada manusia $(16,17)$. Penelitian yang dilakukan Berger juga mengemukakan bahwa oryzanol mampu mencegah peningkatan kadar kolesterol dan trigliserida pada tikus yang diberi diet tinggi lemak (18).

Mekanisme yang terjadi melalui penyerapan kolesterol di usus, baik kolesterol yang berasal dari makanan maupun kolesterol endogen. Oryzanol akan membentuk senyawa kompleks dengan kolesterol yang tidak larut, sehingga kelarutan kolesterol menjadi berkurang dalam larutan asam empedu. Kelebihan kolesterol dibuang bersama feses (19).

\section{Pengaruh Pemberian Combined Food Bekatul terhadap} Kadar LDL

Hasil penelitian menunjukkan terjadi penurunan kadar kolesterol LDL pada kelompok perlakuan yang diberi bekatul dengan dosis yang berbeda. Penelitian yang mendukung hal ini adalah penelitian yang dilakukan oleh Damayanti yang menyatakan bahwa minyak bekatul dan

\section{DAFTAR PUSTAKA}

1. Suharjo dan CM Kusharto. Prinsip-prinsip IImu Gizi. Cetakan 12. Yogyakarta: Kanisius; 2010: hal. 35.

2. Brasher LV. Aplikasi Klinis Patofisiologi: Pemeriksaan dan Manajemen. Edisi 2. Jakarta: EGC; 2008: hal. 270- fraksinya terbukti dapat menghambat oksidasi LDL manusia secara in vitro (20). Proses oksidasi pada LDL akan mengakibatkan peningkatan kadar kolesterol LDL dalam darah. Pemberian bekatul dapat mencegah terjadinya oksidasi karena kandungan vitamin E yang cukup tinggi yaitu mencapai $300 \mathrm{mg} / \mathrm{kg}$. Vitamin E (tokoferol) merupakan vitamin larut lemak alami yang paling efektif dalam memproteksi asam lemak tidak jenuh di membran sel yang sangat penting untuk fungsi dan struktur membran. Mekanisme kerja vitamin E termasuk dalam antioksidan sekunder karena dapat menangkap dan mencegah terjadinya reaksi berantai. Tokoferol menekan peroksidasi lipid melalui penangkapan radikal peroksil termasuk dalam peroksidasi atau melalui reaksi dengan radikal peroksil lipid. $\alpha$-tokoferol merupakan antioksidan pemecah rantai radikal bebas yang kuat dan isomer vitamin E larut lemak paling potensial. Tokotrionel juga menghambat sintesis kolesterol, menurunkan kadar serum kolesterol pada berbagai percobaan pada binatang dan menekan proliferasi sel tumor (21).

Selain tokoferol dan tokotrionel, bekatul juga mengandung -oryzanol dengan komposisi 13-20 kali lebih banyak dari tokoferol dan tokotrienol. $y$-oryzanol dilaporkan dapat menurunkan kadar serum kolesterol, memiliki aktivitas anti-inflamasi, dan dapat menghambat oksidasi kolesterol in vitro. Lemak pada bekatul mengandung sekitar $20 \%$ rice bran oil (RBO) yang kaya akan sejumlah besar asam lemak tak jenuh (70-90\%), khususnya asam oleat dan linoleat (22). Penelitian pada tikus yang diberi RBO melaporkan adanya penurunan yang signifikan pada total serum kolesterol, LDL dan peningkatan eksresi steroid fekal yang dibandingkan dengan konsentrasi yang sama dengan minyak kacang tanah (23).

Beberapa penelitian lain juga telah menunjukkan manfaat fisiologis dari minyak bekatul, salah satunya yaitu kandungan $\gamma$-oryzanol dapat menurunkan kadar LDL, meningkatkan kadar HDL plasma, dan bersifat hipokolesterolemik pada hamster (24). Minyak bekatul juga mempunyai kemampuan meningkatkan sensitivitas insulin dan menekan respon hiperinsulinemik pada tikus diabetes tipe 2, serta $\mathrm{\gamma}$-oryzanol pada minyak bekatul memiliki properti anti-aterogenik yang ditunjukkan dengan penurunan akumulasi kolesterol di aorta pada hamster $(24,25)$.

Bekatul yang tinggi akan kandungan serat pangan sangat potensial untuk menurunkan kadar LDL dalam darah. Wresdiyati et al melaporkan bahwa serat pangan dapat mengikat kolesterol LDL secara langsung, juga mengikat asam empedu dan menghambat sirkulasi enterohepatik asam empedu (26). Mekanisme ini akan memacu kehilangan kolesterol LDL dengan cara meningkatkan pengeluaran kolesterol LDL melalui feses. Hal serupa juga dilaporkan oleh Hartoyo et al yang menyatakan bahwa penambahan beberapa jenis serat pada manusia dapat menurunkan kadar kolesterol LDL (27). Hasil penelitian menunjukkan bahwa pemberian bekatul dapat menurunkan kadar kolesterol total, trigliserida dan LDL dalam serum darah tikus galur wistar. Suplementasi bekatul dalam pakan sebesar 50\% efektif menurunkan kolesterol total, trigliserida dan LDL tikus galur wistar.

290.

3. Bull E dan Morrel J. Kolesterol. Jakarta: Erlangga; 2007: hal. 26-28, 45-46.

4. Hernawati, Wasmen M, Agik S, dan Dewi A. Perbaikan Parameter Lipid Darah Mencit Hiperkolesterolimia 
dengan Suplemen Pangan Bekatul. Majalah Kedokteran Bandung. 2013; 45(1): 1-9.

5. Lestari E. Pengaruh Penambahan Bekatul sebagai Bahan Pengisi Tempe terhadap Kadar Protein Tempe Kedelai. [Skripsi]. Universitas Muhammadiyah Surakarta, Surakarta. 2005.

6. Kusumawati D. Bersahabat dengan Hewan Coba. Yogyakarta: Gadjah Mada University Press; 2004; hal. 73.

7. Bresnahan J. Biological and Physiological Data on Laboratory Animal. United State of America: Kansas State University; 2004.

8. Roy S, Freake HC, and Fernandez ML. Gender and Hormonal Status Affect the Regulation of Hepatic Cholesterol 7 Alpha-hydroxylase Activity and mRNA Abundance by Dietary Soluble Fiber in the Guinea Pig. Atherosclerosis. 2002; 163(1): 29-37.

9. Rideout TC, Harding SV, Jones PJ, and Fan MZ. Guar Gum and Similar Soluble Fiber in the Regulation of Cholesterol Metabolism: Current Understanding and Future Research Priorities. Vascular Health and Risk Management. 2008; 4(5): 1023-1033.

10. Van Bennekum AM, Nguyen DV, Schulthess G, Hauser $\mathrm{H}$, and Phillips MC. Mechanisms of Cholesterollowering Effects of Dietary Insoluble Fibers: Relationship with Intestinal and Hepatic Cholesterol Parameters. British Journal of Nutrition. 2005; 94(3); 331-337.

11. Herpandi. Aktivitas Hipokolesterolemik Tepung Rumput Laut pada Tikus Hiperkolesterolimia. [Tesis]. Sekolah Pascasarjana Institut Pertanian Bogor, Bogor. 2005.

12. Umar S, Triastati M, and Rob M. Produk Ekstrusi Berbasis Tepung Ubi Jalar. Jurnal Teknologi dan Industri Pangan. 2007; 18(1): 40-43.

13. Ramadhan FF. Pengaruh Pemberian Nata De Coco terhadap Kadar Kolesterol Total dan Trigliserida pada Tikus Hiperkolesterolemia. [Artikel IImiah]. Universitas Diponegoro, Semarang. 2011.

14. Yamada N. Control of Triglyceride. Asian Medical Journal. 2007; 44(1): 42-47.

15. Maryanto S dan Fatimah S. Pengaruh Pemberian Jambu Biji (Psidium Guava L) pada Lipid Serum Tikus (Sprague Dawley) Hiperkolesterolemi. Jurnal Kedokteran Media Medika Indonesia. 2004; 39(2): 105-111.

16. Wirawati CU and Nirmagustina DE. Studi In Vivo Produk Sereal dari Tepung Bekatul dan Tepung Ubi Jalar sebagai Pangan Fungsional. Jurnal Teknologi Industri dan Hasil Pertanian. 2009; 14 2): 142-147.

17. Cicero AF and Gaddi A. Rice Bran Oil and Gamma- oryzanol in The Treatment of Hyperlipoproteinaemias and Other Conditions. Phytotherapy Research. 2005; 15(4): 277-289.

18. Berger A, Rein D, Schäfer A, et al. Similar Cholesterollowering Properties of Rice Bran Oil, with Varied Gamma-oryzanol, in Mildly Hipercholesterolemic Men. European Journal of Nutrition. 2005; 44(3): 163173.

19. Son MJ, Rico CW, Nam SH, and Kang MY. Influence of Oryzanol and Ferulic Acid on the Lipid Metabolism and Antioxidative Status in High Fat-Feed Mice. Journal of Clinical Biochemistry and Nutrition. 2010; 46(2): 150156.

20. Damayanti ES, Madanijah, dan Sofia, IR. Sifat Fisiokimia dan Daya Terima Tepung Bekatul Padi Awet sebagai Sumber Serat Makanan. Di dalam: Nuraida L dan Hariyadi RD (Ed). Pangan Tradisional Basis Bagi Industri Pangan Fungsional dan Suplemen. Bogor: Pusat Kajian Makanan Tradisional, IPB; 2005.

21. Phenpham C. Antioxidants and Antioxidant Activities of Pigmented Rice Varieties and Rice Bran. [Tesis]. Universitas Mahidol, Thailand. 2007.

22. Putrawan IDG, Maryana R, dan Rosmayanti I. Ekstraksi Minyak Dedak Padi Menggunakan Isopropil Alkohol. Seminar Nasional Teknik Kimia Indonesia-SNTKI 2009. Bandung, 19-20 Oktober 2009.

23. Tahira R, Rehman A, and Butt MA. Characterization of Rice Bran Oil. Journal of Agricultural Research. 2007; 45(3): 225-230.

24. Wilson TA, Nicolosi RJ, Woolfrey B, and Kritchevsky D. Rice Bran Oil and Oryzanol Reduce Plasma Lipid and Lipoprotein Cholesterol Concentrations and Aortic Cholesterol Ester Accumulation to a Greater Extent than Ferulic Acid in Hypercholesterolemic Hamsters. The Journal of Nutritional Biochemistry. 2007; 18(2): 105-120.

25. Chen CW, Cheng HH. A Rce Bran Oil Diet Increases LDLReseptor and HMG-CoA Reduktase mRNA Expression and Insulin Sensitivity in Rats with Streptozotocin/nicotinamide Induced Type 2 Diabetes. Journal of Nutrition. 2006; 136(6): 1472-1476.

26. Wresdiyati $T$, Hartanta $A B$, dan Astawan M. Tepung Rumput Laut Eucheuma Cottonii) Menaikkan Level Superoksida Dismutase (SOD) Ginjal Tikus Hiperkolesterolimia. Jurnal Veteriner. 2011; 12(2): 126-135

27. Hartoyo A, Dahrulsyah D, Sripalupi N, dan Nugroho P. Pengaruh Fraksi Karbohidrat Kacang Komak (Lablab Purpureus (L) Sweet) terhadap Kolesterol dan Malonaldehid Serum Tikus Percobaan yang Diberi Ransum Tinggi Kolesterol. Jurnal Teknologi dan Industri Pangan. 2008; 19(1): 25-31. 